\title{
Hubungan antara Konsumsi Buah dengan Risiko Obesitas pada Mahasiswa Fakultas Kedokteran Universitas YARSI
}

\section{The Relationship between Fruit Consumption and Obesity Risk in Medical Students of YARSI Medical School}

\author{
Ayuvy Monzalitza ${ }^{1}$, Nur Asiah ${ }^{2}$ \\ ${ }^{1}$ Student Faculty of Medicine, YARSI University, Jakarta \\ ${ }^{2}$ Department of Nutrition, Faculty of Medicine, YARSI University, Jakarta \\ Jalan Letjen. Suprapto, Cempaka Putih, Jakarta 10510 \\ Telephone (021) 4206674, 4206675, 4206676 \\ Correspondence Email: nur.asiah@yarsi.ac.id
}

\begin{abstract}
Abstrak
Latar Belakang Obesitas diketahui memiliki dampak negatif terhadap kesehatan. Orang dengan obesitas lebih mudah terserang penyakit degeneratif seperti hipertensi, penaykit jantung, diabetes mellitus, batu empedu bahkan kanker. Obesitas dapat disebabkan asupan makanan tinggi kalori dan rendah serat seperti buah dan sayur. Asupan buah dan sayur pada remaja masih tergolong rendah, di bawah rekomendasi WHO. Tujuan Penelitian ini bertujuan untuk melihat hubungan antara asupan buah dan indeks massa tubuh pada mahasiswa fakultas kedokteran Universitas YARSI Jakarta. Metode Penelitian ini bersifat cross sectional (studi potong lintang) pada 47 orang mahasiswa fakultas kedokteran Universitas YARSI Jakarta pada tahun 2017. Data yang dinilai adalah indeks massa tubuh dan asupan buah. Tingkat asupan buah dinilai dengan Food Frequency Questionnaire (FFQ). Analisis statistik menggunakan uji Chi-Square dan diolah menggunakan SPSS Statistik Versi 23. Hasil Penelitian Prevalensi obesitas pada mahasiswa fakultas kedokteran Universitas YARSI sebesar $46.8 \%$ dengan riwayat obesitas dari pihak ibu dan ayah. Hanya 34\% mahasiswa yang mengkonsumsi buah tergolong cukup ( $>2-3 \mathrm{kali} / \mathrm{minggu})$. Mahasiswa yang tergolong obesitas sebagian besar mengkonsumsi buah dalam kategori kurang ( $p>0.05$ ). Terdapat $68.2 \%$ mahasiswa dengan indeks massa tubuh tergolong obesitas yang mengkonsumsi buah dalam kategori kurang. Simpulan Tidak terdapat hubungan bermakna antara indeks massa tubuh dengan tingkat konsumsi buah pada mahasiswa fakultas kedokteran Universitas YARSI Jakarta. Diskusi Dari 47 responden yang berpartisipasi, 22 orang memiliki obesitas dimana 15 orang (68.2\%) kurang mengkonsumsi buah. Asupan camilan pada mahasiswa fakultas kedokteran Universitas YARSI sebagian besar bukanlah buah karena adanya anggapan bahwa buah memiliki harga yang mahal dan belum adanya kesadaran mahasiswa bahwa buah memiliki kalori rendah dan serat yang tinggi yang dapat mencegah obesitas.
\end{abstract}

Kata kunci: Indeks massa tubuh; buah; obesitas 


\section{Abstract}

Background: Obesity has a negative effect in our health, such as hypertension, cardiovascular disease, diabetes mellitus, gallbladder stone even, cancer. The cause of obesity was an unbalance calories intake and calories output. Fruits and vegetables are a low calories foods. The fruit intake in young adult is still lower than what WHO recommend (4-5 portion/day). Aim of the study: The aim of the study was to assess the relationship between fruit intake and body mass index of 47 YARSI medical Students in 2017. Method: It was a cross sectional study. The data we collected were fruit consumption and body mass index. Fruit consumption data were assessed by Food Frequency Questionnaire (FFQ). Statistics were analyzed using Chi-Square test and SPSS Statistic 23 Version. Result of the study: Obesity prevalence in YARSI medical students was $46.8 \%$ with obesity history from mother and father. It was only $43 \%$ medical students who eat fruit $>2-3 x /$ week (enough categorized). The most obesity medical students (68.2\%) had lack of fruit consumption ( $p>$ 0.05). Summary: There was no relationship between fruit intake and body mass index in YARSI medical students. Discussion: From 47 respondent who contribute, 22 people have an obesity, in which 15 people (68.2\%) not consuming enough fruits. Fruits were not the main choice of snack in YARSI medical students. They thought that fruit is expensive and they didn't realize that fruit consumption was a healthy because fruits contained fiber to prevent from obesity.

Keywords: body mass index, fruit, obesity

\section{Pendahuluan}

Obesitas memiliki dampak negatif terhadap kesehatan. Orang dengan obesitas lebih mudah terserang penyakit degeneratif seperti hipertensi, penyakit jantung, diabetes mellitus, batu empedu bahkan kanker. Obesitas dapat disebabkan asupan makanan tinggi kalori dan rendah serat seperti buah dan sayur.

Suatu penelitian yang dilakukan oleh Rachman dkk pada tahun 2017 terhadap 85 siswa SMP kelas VIII di Denpasar Bali menyebutkan bahwa terdapat $60 \%$ siswa lakilaki yang memiliki asupan buah dan sayur tergolong baik dan $73 \%$ siswa wanita dengan asupan buah dan sayur tergolong baik. Asupan buah dan sayur yang tergolong baik ini dipengaruhi oleh pengetahuan gizi,preferensi makanan, ketersediaan makanan, paparan terhadap media dan pendapatan orang tua (Rachman dkk, 2017).

$$
\text { Buah-buahan dan sayur-mayur }
$$
merupakan bahan makanan dengan kandungan rendah kalori sehingga harus dikonsumsi dalam jumlah besar untuk menimbulkan rasa kenyang dalam waktu lama. Buah dan sayuran kaya akan serat, vitamin, mineral dan zat-zat gizi yang bermanfaat untuk kesehatan. Konsumsi buah dan sayur secara teratur dapat menurunkan risiko obesitas, kanker, penyakit kardiovaskuler, stroke, hipertensi, dan semua penyakit degeneratif.Rekomendasi WHO untuk konsumsi buah dan sayur dalam menurunkan penyakit-penyakit kronik adalah sebanyak 400$500 \mathrm{gram} /$ hari atau 5-6 porsi sehari.Penelitian di Australia menyebutkan bahwa asupan buah dan sayur pada 2397 orang remaja dan dewasa muda usia 18-34 tahun sebesar 128 gram/hari 
(0.9 porsi) untuk buah dan sayur sebanyak 205 gram (2 porsi)/hari (Nour dkk, 2017).

Suatu penelitian menyebutkan bahwa pengaruh asupan buah dan sayur pada remaja dan usia dewasa muda dapat mempengaruhi kondisi psikologis seperti berkurangnya perasaan depresi, cemas, penerimaan dalam lingkungan sosial, meningkatnya kesehatan karena vitamin dan antioksidan yang dikandung dalam buah dan sayuran (Conner dkk, 2017).

Penelitian lain melaporkan bahwa asupan buah dan sayuran pada $82.8 \%$ mahasiswa yang berasal dari 27 universitas pada 26 negara-negara di Asia, Afrika dan Amerika kurang dari rekomendasi WHO (5 porsi/hari). Sebanyak 17.789 mahasiswa dengan rata-rata usia 20.8 tahun dalam penelitian ini mahasiswa dari Jamaika, Filipina dan Barbados mengkonsusmi $\leq 2.5$ porsi buah dan sayur setiap; sedangkan mahasiswa dari Mauritius, Tunisia, dan Ivory Coast mengkonsumsi $\geq 3.9$ porsi buah dan sayur setiap hari (Peltzer dan Pengpid, 2015).

Asupan buah dan sayur pada mahasiswa masih tergolong rendah karena tingginya frekuensi bahan makanan cepat saji di kalangan remaja baik sebagai bahan makanan utama ataupun camilan.Penelitian ini bertujuan untuk melihat hubungan antara asupan buah dan indeks massa tubuh pada mahasiswa fakultas kedokteran Universitas YARSI Jakarta Penelitian.

\section{Bahan dan Metoda Penelitian}

Penelitian ini bersifat cross sectional (studi potong lintang) pada 47 orang mahasiswa fakultas kedokteran Universitas YARSI Jakarta pada tahun 2017. Data yang dinilai adalah indeks massa tubuh dan asupan buah. Tingkat asupan buah yang dinilai dengan food Frequency Questionnaire (FFQ). Analisis statistik menggunakan uji Chi-Square dan diolah menggunakan SPSS Statistik Versi 23.

\section{Hasil Penelitian}

Hasil penelitian menunjukkan bahwa sebagian besar mahasiswa kedokteran Universitas YARSI mengkonsumsi buah tergolong kurang ( $<2-3$ porsi/hari).

Terdapat 22 orang mahasiswa yang tergolong obesitas $(46.8 \%)$ dan sebagian besar tidak memiliki riwayat keturunan obesitas dalam keluarga.

Tabel 1. Karakteristik responden

\begin{tabular}{lrl}
\hline Karakteristik & Jumlah $(\mathrm{n})$ & Persentase $(\%)$ \\
\hline Jenis kelamin & & \\
Laki-laki & 12 & 25.5 \\
Perempuan & 35 & 74.5 \\
Usia (tahun) & 19 & 40.4 \\
20 & 23 & 48.9 \\
21 & 5 & 10.6 \\
22 & 10 & 21.3 \\
Riwayat obesitas dalam keluarga & 37 & 78.7 \\
Ada & 3 & 30 \\
Tidak & 5 & 50 \\
Keturunan obesitas & 2 & 20 \\
Ayah & & \\
Ibu & & 46.8 \\
Ayah dan ibu & 22 & 53.2 \\
Indeks Massa Tubuh (kg/m2) & 25 &
\end{tabular}


Tingkat konsumsi buah

Cukup ( $\geq 2-3$ porsi/hari)

Kurang ( $<2-3$ porsi/hari)

$16 \quad 34.0$

Dari 47 responden, 35 orang (74.5\%) merupakan perempuan. Dengan usia 20-22 tahun dengan 23 orang (48.9\%) berusia 21 tahun. 10 orang memiliki riwayat obesitas dalam keluarga. 22 orang (46.8\%) memiliki obesitas. Dan 31 orang (66\%) kurang dalam mengkonsumsi buah.

Tabel 2 Indeks Massa Tubuh

\begin{tabular}{llll}
\hline & Obesitas & Tidak obesitas & Total \\
Laki-laki & $8(66.7 \%)$ & $4(33.3 \%)$ & $12(100 \%)$ \\
Perempuan & $14(40.0 \%)$ & $21(60 \%)$ & $35(100 \%)$ \\
Keturunan obesitas & & & \\
Ada & $8(80.0 \%)$ & $2(20.0 \%)$ & $10(100 \%)$ \\
Tidak ada & $14(37.8 \%)$ & $23(62.2 \%)$ & $37(100 \%)$ \\
\hline
\end{tabular}

Dari 12 responden laki-laku, 8 orang (66.7\%) memiliki obesitas. Dan dari 35 responden perempuan, 14 orang $(40 \%)$ memiliki obesitas. Dari 10 orang yag memiliki keturunan obesitas, 8 orang $(80 \%)$ memiliki obesitas dan dari 37 orang yang tidak memiliki keturunan obesitas, 14 orang $(37.8 \%)$ memiliki obesitas.

Tabel 3. Hubungan asupan buah dan obesitas

\begin{tabular}{lllll}
\hline & & & & \\
& Cukup & Kurang & Total & \\
\hline Obesitas & $7(31.8 \%)$ & $15(68.2 \%)$ & $22(100 \%)$ & $\mathrm{p}=0.763$ \\
Tidak Obesitas & $9(36 \%)$ & $16(64.0 \%)$ & $25(100)$ & \\
\hline
\end{tabular}

Dari 22 orang yang memiliki obesitas, 15 orang (68.2\%) kurang dalam mengkonsumsi buah dan hanya 7 orang (31.8\%) yang cukup dalam mengkonsumsi buah.

\section{Diskusi}

Hasil penelitian ini menunjukkan bahwa asupan buah pada sebagian besar mahasiswa fakultas kedokteran Universitas YARSI (66\%) tergolong kurang (< 2-3 porsi/hari). Hasil penelitian ini sejalan dengan penelitian di sebuah SMP negeri Jakarta menunjukkan bahwa rata-rata konsumsi buah dan sayur remaja SMPN 98 Jakarta tahun 2017 adalah $85,1 \pm 26,58 \mathrm{~g} /$ hari. Sementara rekomendasi WHO konsumsi buah dan sayur 400 g/hari.Konsumsi buah dan sayur per kapita di seluruh dunia menunjukkan bahwa sebanyak 20-50\% di bawah rekomendasi minimal.Menurut laporan CDC pada tahun 2013, rata-rata asupan buah pada remaja di Amerika sebanyak $1 \mathrm{kali} /$ hari dan rata-rata asupan sayur sebanyak 1,3 kali/hari Thailand memiliki rata-rata asupan buah dan sayur sebanyak 3,7 porsi/hari. Jika dibandingkan dengan Indonesia, penduduk memiliki rata-rata asupan buah dan sayur yang lebih rendah, yaitu 3,2 porsi/hari. Selain itu, rata-rata konsumsi buah dan sayur penduduk Indonesia sebanyak 108,8 g/hari. Berdasarkan Laporan Hasil Riskesdas Provinsi DKI Jakarta tahun 2013 , hanya sekitar $1,4 \%$ penduduk di Jakarta Selatan yang mengonsumsi buah dan sayur sebanyak 5 porsi atau lebih per hari dalam seminggu. Angka tersebut menunjukkan nilai yang lebih rendah dibanding angka provinsi $(3,7 \%)$ dan nasional (6,5\%) (Anggraini dan Sudiarti, 2018).

Berdasarkan penelitian ini didapatkan frekuensi konsumsi buah tidak memiliki hubungan yang bermakna dengan tingkat obesitas. Tetapi persentase mahasiswa dengan obesitas yang kurang mengkonsumsi buah sebanyak $68 \%$, lebih banyak dibandingkan persentase mahasiswa tanpa obesitas yang cukup mengkonsumsi buah (64\%). 
Hasil penelitian ini tidak sejalan dengan penelitian Wardhani dkk (2015) yang menunjukkan bahwa asupan buah-buahan berkaitan secara bermakna dengan perubahan berat badan.Pada penelitian ini dijelaskan bahwa buah-buahan memiliki kepadatan energi yang rendah karena memiliki kandungna air yang tinggi, kandungan energi yang rendah dan kandungan serat makanan yang tinggi.Oleh karena itu buah dan sayur mampu meningkatkan rasa kenyang dan mengurangi rasa lapar.Buah dan sayur juga mengandung flavonoid dan kelompok fitokimia yang mungkin memiliki sifat antiobesitas. Hal ini membuat asupan buah dan sayur mampu mencegah obesitas (Kharisma, 2015).

Umumnya buah mengandung serat larut air. Serat larut air seperti pektin dan hemiselulosa mempunyai kemampuan menahan air dan dapat membentuk cairan kental dalam saluran pencernaan. Sehingga makanan kaya akan serat memiliki waktu cerna lebih lama dalam lambung dan memberikan rasa kenyang lebih lama. Serat akan menarik air dan memberi rasa kenyang lebih lama sehinggga mencegah untuk mengkonsumsi makanan lebih bnayak. Makanan dengan kandungan serat yang tinggi biasanya mengandung kalori yang rendah, kadar gula dan lemak yang rendah sehingga menurunkan kadar kolesterol darah dan mencegah obesitas.

Perbedaan hasil penelitian ini dengan hasil penelitianlain disebabkan asupan selingan mahasiswa fakultas kedokteran Universitas YARSI bukanlah buah dan sayur tetapi makanan lainnya. Selain itu ada anggapan bahwa harga buah tergolong mahal sehingga asupan camilan bukan dari buah tetapi dari bahan makanan lain. Sebagian besar buah yang dikonsumsi dalam penelitian ini adalah jeruk, semangka, papaya, mangga, pisang dan melon, yang harganya tidak terlalu mahal dan mudah diperoleh. Buah-buahan ini terdiri dari 40-100 gram/porsinya dengan kandungan serat 3-6 gram per porsi.Sehingga jika mengkonsumsi 2-3 porsi/hari belum mencukupi rekomendasi asupan serat oleh WHO yang menganjurkan sebanyak 25 gram serat setiap harinya (Waspadji dan Suyono, 2011).

\section{Simpulan}

Tidak terdapat hubungan bermakna antara indeks massa tubuh dengan tingkat konsumsi buah pada mahasiswa fakultas kedokteran Universitas YARSI Jakarta.

\section{Daftar Pustaka}

Anggranini NA, Sudiarti T. 2018. Faktor Dominan Konsumsi Buah dan Sayur pada Remaja di SMPN 98 Jakarta. Indonesian Journal of Human Nutrition, Vol 5, No.1:18:32.

Aryani D. 2017. Asupan Serat Pangan dan Pengetahuan tentang Serat pada Remaja di Dua SMA Kota Bogor. Departemen Gizi Masyarakat Fakultas Ekologi Manusia Institut Pertanian Bogor.Skripsi.

Conner TS, Brookie KL, Carr AC, Mainvil LA, Vissers MCM, Wouwe JP. 2017. Let them eat fruit! The effect of fruit and vegetable consumption on psychological well-being in young adults: A randomized controlled trial. PLoS 12(2): e0171206.

Kharisma WD. 2015. Keterkaitan antara konsumsi buah dan sayur serta gaya hidup dengan kejadian kegemukan pada mahasiswa TPB-IPB. Skripsi. Institut Pertanian Bogor.

Nour M, Sui Z, Grech A, Rangan A, McGeechan K, Allman-Farinelli M. 2017. The fruit and 
vegetable intake of young Australian adults: a population perspective. Public Health Nutrition: 20(14), 2499:2512.

Peltzer K, Pengpid S. 2015. Correlates of healthy fruit and vegetable diet in students in low, middle and high income countries. International Journal of Public Health; Vol 60 (1): 79-90.
Rachman BN, Mustika IG, Kusumawati IGAW. 2017. Faktor yang berhubungan dengan perilaku konsumsi buah dan sayur siswa SMP di Denpasar. Jurnal Gizi Indonesia, $6(1): 9-16$.

Waspadji S, Suyono S. 2011. Daftar Bahan Makanan Penukar. Badan Penerbit FKUI Jakarta 